\title{
Youngsters and technology
}

Citation for published version (APA):

de Grip, A., \& Willems, E. (2003). Youngsters and technology. Research Policy, 32(10), 1771-1781.

https://doi.org/10.1016/S0048-7333(03)00079-9

Document status and date:

Published: 01/01/2003

DOI:

10.1016/S0048-7333(03)00079-9

Document Version:

Publisher's PDF, also known as Version of record

Document license:

Taverne

\section{Please check the document version of this publication:}

- A submitted manuscript is the version of the article upon submission and before peer-review. There can be important differences between the submitted version and the official published version of record.

People interested in the research are advised to contact the author for the final version of the publication, or visit the DOI to the publisher's website.

- The final author version and the galley proof are versions of the publication after peer review.

- The final published version features the final layout of the paper including the volume, issue and page numbers.

Link to publication

\footnotetext{
General rights rights.

- You may freely distribute the URL identifying the publication in the public portal. please follow below link for the End User Agreement:

www.umlib.nl/taverne-license

Take down policy

If you believe that this document breaches copyright please contact us at:

repository@maastrichtuniversity.nl

providing details and we will investigate your claim.
}

Copyright and moral rights for the publications made accessible in the public portal are retained by the authors and/or other copyright owners and it is a condition of accessing publications that users recognise and abide by the legal requirements associated with these

- Users may download and print one copy of any publication from the public portal for the purpose of private study or research.

- You may not further distribute the material or use it for any profit-making activity or commercial gain

If the publication is distributed under the terms of Article $25 \mathrm{fa}$ of the Dutch Copyright Act, indicated by the "Taverne" license above, 


\title{
Youngsters and technology
}

\author{
Andries de Grip*, Ed Willems \\ Division of Labour Market and Training, Research Centre for Education and the Labour Market (ROA), \\ Maastricht University, P.O. Box 616, 6200 MD Maastricht, The Netherlands
}

Received 28 October 2002; received in revised form 7 March 2003; accepted 14 March 2003

\begin{abstract}
The decreasing number of students in technical studies becomes a major threat for technology-driven economic growth. In this paper, we analyse whether the choices of young people for technical studies or occupations are based on economic, socio-psychological, or other motives. Apart from the traditional human capital variables and personal and social background characteristics, we also link pupils' vocational choices to their value-judgement with respect to technological development. We find that the choice for technical studies and jobs is only slightly affected by economic motives. Also negative views on the economic and social consequences of technological developments do not affect the choice for technical studies or jobs. Much more important reasons for not choosing a technical or science study are both poor school grades in Maths and Sciences and lack of interest in technological developments. Moreover, girls scarcely choose technical studies even if they have high grades in Maths and Sciences. Policies to increase the inflow of youngsters in technical studies should therefore focus on a long-term strategy that attempts to increase the interest of youngsters in technical issues. Moreover, policies should focus on girls with high grades in Maths and Sciences as a specific target group instead of mass campaigns focusing on the good employment opportunities of technical studies.
\end{abstract}

(c) 2003 Elsevier Science B.V. All rights reserved.

Keywords: Youngsters; Technology; Educational and occupational choice

\section{Introduction}

In a world characterised by international competition, sufficient numbers of technically educated persons are a necessary condition for technologyintensive economic growth (cf. Murphy et al., 1991; Pearson et al., 2000). In the early 1990s, policy-makers in many industrialised countries became aware that the decreasing interest in technical and science studies could diminish future potential for economic growth (see, e.g. European Commission, 1993).

\footnotetext{
* Corresponding author. Tel.: +31-43-3883647; fax: +31-43-3884914.

E-mail address: a.degrip@roa.unimaas.nl (A. de Grip).
}

The threat of a shortage of personnel with technical education and science graduates has led the governments in many OECD countries to initiate large campaigns to stimulate students to choose technical studies or occupations. However, if government policy in this area is to be effective, it is important to identify the factors which determine young people's choice for a technical study or job.

In this article, we will analyse the determinants of youngsters' choice for the technical field. ${ }^{1}$ We focus our analysis on pupils of 14 and 15 years old in The Netherlands who have to choose a particular 'stream' of subjects that affects their opportunities for further

\footnotetext{
${ }^{1}$ In this paper we define the technical field in a broad sense including all 'hard' sciences.
} 
studies. Our multidisciplinary empirical model builds on various theories on vocational choice. We combine the hypothesis from the economic human capital theory emphasising the labour market perspectives of the various studies with the hypotheses of the sociological model of social stratification that expects that vocational choices are based on youngsters' social background and the attitude-behaviour model and value-expectation model from socio-psychological theory that emphasize youngsters' attitudes and subjective values as determinants of vocational choices.

We will, in particular, focus on youngsters' view on technological progress and the image which they have of the work of people with technical education as explanatory factors for the choice of a technical study. ${ }^{2}$ With youngsters' view on technological progress both their general interest in technological developments, and their views of the economic and social consequences of technological progress are indicated. The latter includes, for example, the expected implications of particular technological innovations for unemployment and environmental pollution. In this article, the image of working in technical jobs is considered from two points of view: the expected labour market position (employment and income), and a number of qualitative aspects of the work. It is also important that the image that young people have of technical education should be related to their perceptions of other-competing-vocational options. Moreover, we will analyse to what extent personal characteristics and social backgrounds determine the vocational choices of young people. As known technical studies and jobs are much less popular among girls than among boys. Moreover, youngsters' cognitive capacities may affect their vocational choices. For this purpose we will take account of youngsters' school grades for Math and Sciences and Arts subjects.

We will analyse youngsters' decisions related to their vocational specialisation at three important moments in their educational careers in The Netherlands:

(i) At about 12 years of age, pupils coming from primary school choose either a Preparatory Voca-

\footnotetext{
${ }^{2}$ Here too we use a broad definition of technical education (see Section 3).
}

tional Education (PVE), which may or may not be in a technical field, or a form of general secondary education.

(ii) The group who chooses a general education must select a particular 'stream' of subjects when they are 15-16 years old.

(iii) The next important choice is the choice of further vocational education, or an occupation after leaving general secondary education.

The article is structured as follows. Section 2 briefly discusses the relevant theories of vocational choice. Section 3 describes the data we used. Section 4 discusses young people's view on technological progress and the image of technical education. Section 5 presents some stylised facts on the extent to which the various choices in youngsters' educational career affect the choice for technical studies and jobs and in Section 6 we present the results of a multivariate analysis of young people's choices for technical studies or jobs. Section 7 concludes and discusses the policy implications of our analysis.

\section{Theories on vocational choice}

The vocational choice behaviour of youngsters can be analysed from various theoretical perspectives. In economic literature, human capital theory offers an important explanation for an individual's educational choices (see, e.g. Schultz, 1961; Becker, 1962). In human capital theory educational choices are seen as investment decisions, in which the returns (i.e. the present value of future returns), are weighed against the costs. The costs of training consist, on the one hand, of the direct costs such as tuition fees, the cost of books, etc. and, on the other hand, indirect 'opportunity' costs, i.e. the wages not earned because it is impossible to be active in the labour market during the course. The returns on an educational investment derive from the higher income which can be earned with a higher level of education. Moreover, the returns for undertaking further education can also become manifest in better opportunities to find a job with a particular vocational education. However, individuals might not have perfect information on the labour market perspectives of the various fields of study, which may lead to imperfect anticipation and 
mismatches between supply and demand in the labour market (Borghans et al., 1996).

Sociological studies on social stratification emphasize the social backgrounds as determinants of the educational and occupational choices of young people. Following Blau and Ducan (1967) many studies focus on the educational attainment of both parents as a determinant of vocational choices (e.g. Boudon, 1974; Sieben et al., 2001). Other studies focus on the large gender differences in educational and occupational choices (e.g. Blau and Hendricks, 1979).

In socio-psychological literature the emphasis is on young people's attitudes, subjective values and the expectation of success as dominant explanations for educational choice behaviour. A good example of such models, focusing on the differences between boys and girls, is the model of Eccles (1987). The latter part of this model, the value-expectation model describes the process of weighing several alternatives, in which the values refer to, e.g. utility, pleasure, efforts and other cost and benefits and the expectations refer to the perceived probability that the alternative chosen will contribute to these values. Another model that describes the individual choices is the attitude-behaviour model developed by Fishbein and Ajzen (1975). In their model the most relevant determinants of individual behaviour are 'attitudes' and 'subjective norms'. These subjective norms consist of the opinions of a peer group (normative beliefs) and the motivation to conform to these beliefs.

\section{Data}

For our analysis of the vocational choice behaviour of youngsters, we surveyed 14- and 15-year-old pupils attending secondary education in The Netherlands, using a written questionnaire. For the survey, we approached a representative sample of 197 schools, of which 95 were prepared to participate in the survey. The advantage of this survey design was that we could make a random choice of one or two classes in each school that participated in the survey. ${ }^{3}$ All pupils in these classes were required to answer the questionnaire during school-time. This enabled us to prevent any se-

\footnotetext{
${ }^{3}$ In larger schools we surveyed one class in each of two different educational categories.
}

Table 1

Respondents analysed by educational category and gender

\begin{tabular}{lrrr}
\hline Educational category & Boys & Girls & Total \\
\hline $\begin{array}{l}\text { Preparatory Vocational Education (PVE): } \\
\quad \text { technology (\%) }\end{array}$ & 44 & 7 & 28 \\
$\begin{array}{l}\text { Preparatory Vocational Education (PVE): } \\
\text { other (\%) }\end{array}$ & 12 & 31 & 20 \\
$\begin{array}{l}\text { Lower General Secondary Education } \\
\quad \text { (LGSE) (\%) }\end{array}$ & 27 & 32 & 29 \\
$\begin{array}{l}\text { Higher General Secondary Education } \\
\quad(\text { HGSE) }(\%)\end{array}$ & 18 & 29 & 23 \\
$\quad$ Total & 1285 & 1021 & 2315
\end{tabular}

lectivity in the response related to the youngsters' interest in science and technology or technical studies. ${ }^{4}$

Table 1 shows the response, differentiated by educational category and gender. In The Netherlands, pupils coming from primary school can choose either Preparatory Vocational Education, which may be in the technical field or not, or general secondary education at a low level or high level. ${ }^{5}$ The four types of education covered represent all kinds of secondary education in The Netherlands, so that we can make nationally representative statements based on this survey. The questionnaire focuses on three moments of choice:

(i) the choice of secondary school at the end of primary education;

(ii) the curriculum specialisation choice at the age of 15 or 16 years;

(iii) pupils' intended choices at the time they leave secondary education.

For the four educational categories we used slightly different questionnaires, in which we defined the 'technical field' in terms of the studies in intermediate and higher vocational education and university that the pupils could choose after their secondary education. At the various levels we distinguished between four and seven different specialisations. At the university level, for instance, we distinguished between Science

\footnotetext{
${ }^{4}$ An analysis based on a survey among a random group of youngsters would probably suffer from a large selectivity-bias in the response, as the response among those with less interest in science and technology will probably be low.

5 The latter is rather similar to the distinction between $\mathrm{O}$ and $\mathrm{A}$ levels.
} 
Table 2

Weighted response by educational category and gender

\begin{tabular}{lrrr}
\hline Educational category & Boys & Girls & Total \\
\hline PVE: technology (\%) & 26 & 3 & 15 \\
PVE: other (\%) & 9 & 24 & 16 \\
LGSE (\%) & 30 & 29 & 30 \\
HGSE (\%) & 35 & 44 & 39 \\
Total & 1134 & 1176 & 2315 \\
\hline
\end{tabular}

and technology, Medical sciences, Agricultural sciences, Economics and business administration, Law, Social sciences and Arts.

We have used a stratified sample of educational categories within schools. This enables to present results by educational categories. The total response to the survey consisted of 2315 pupils, clustered in 95 participating schools. To be able to draw conclusions at an aggregate level, we weighted the sample. The weighted response by educational category and gender is given in Table 2 .

\section{Youngsters' view on technology and the image of technical education}

In analysing young people's view on technology we have distinguished between how 'interesting' they find it and what they think the 'consequences of technology' may be. These views are measured using an instrument developed by de Klerk Wolters (1989). This instrument consists of a number of Likert scales, each with a number of items, on which the students can indicate, using a five-point scale, the extent to which they agree (see also Mueller, 1986). We selected 16 items, spread over the two elements of interest and consequences. ${ }^{6}$ These items range from "There should be more TV programs on science \& technology", "If something new is invented, I would like to know more of it" (interest) to "Technological progress is important for the future of our country"; "Technological developments cause high unemployment" and "I think the world changes too fast due to technological developments" (consequences).

\footnotetext{
6 The reliability of these scales was found to be sufficiently reliable. Crombach's $\alpha$ is 0.82 and 0.63 for 'interest' and 'consequences', respectively.
}

Table 3

Interest in technology by educational category and gender

\begin{tabular}{llll}
\hline Educational category & \multicolumn{2}{l}{ Score $^{\mathrm{a}}$} & \multirow{2}{*}{$t$-value difference } \\
\cline { 2 - 3 } & Boys & Girls & \\
\hline PVE: technology & 3.73 & 2.80 & 15.07 \\
PVE: other & 3.17 & 2.34 & 12.06 \\
LGSE & 3.23 & 2.25 & 9.39 \\
HGSE & 3.17 & 2.34 & 7.42 \\
Total & 3.32 & 2.33 & 29.28
\end{tabular}

${ }^{\text {a }}$ A score higher than 3 indicates a positive attitude.

Table 3 shows the average level of interest in technology among boys and girls. A score higher than 3 indicates a relatively high level of interest, and a score lower than 3 represents limited interest. The most striking fact shown in this table is that girls' interest in technology is clearly less than that of boys. Regardless of the type of education which they are doing, girls' interest in technology is below the middle of the scale. Boys in all educational categories, in contrast, are reasonably interested in technology. Multivariate analyses show that pupils with high grades for Math and Sciences are more interested in technology. ${ }^{7}$ Moreover, as might be expected, Preparatory Vocational Education students in 'technology' are significantly more interested than students in all other educational categories. But it is striking that the girls who are taking this type of education are not very interested in technology. ${ }^{8}$ It is also striking that the interest in technology among Preparatory Vocational Education students in other vocational specialisations, and especially among the boys, is fairly high. This could indicate that, even at this young age, there is a substantial group of young people who are lost to the technical field although they are interested in technology.

Table 4 provides an overview of students' views in relation to the social and economic consequences of technology. Just as we saw in measuring interest in technology, the boys have a clearly more positive image of these consequences than the girls, although

\footnotetext{
${ }^{7}$ The results of these multivariate analyses can be obtained from the authors.

8 A multivariate analysis shows that the interest in technology of the students in the technical specialisation in Preparatory Vocational Education is larger when the father of the student also has a technical educational background.
} 
Table 4

Opinions regarding the consequences of technological progress, by educational category and gender

\begin{tabular}{llll}
\hline Educational category & \multicolumn{2}{l}{ Score $^{\mathrm{a}}$} & \multirow{2}{*}{$t$-value difference } \\
\cline { 2 - 3 } & Boys & Girls & \\
\hline PVE: technology & 3.75 & 3.51 & 3.38 \\
PVE: other & 3.38 & 3.23 & 2.52 \\
LGSE & 3.55 & 3.30 & 6.59 \\
HGSE & 3.63 & 3.39 & 5.75 \\
Total & 3.62 & 3.33 & 13.60 \\
\hline
\end{tabular}

${ }^{\text {a }}$ A score higher than 3 indicates a positive attitude.

the differences are less remarkable than was seen in relation to interest in technology. In general, it can be seen that boys have a fairly positive view on the consequences of technological progress. But girls are also positive, in balance. There are no great differences between the four educational categories which we have distinguished, although students that take the 'technology' specialisation in Preparatory Vocational Education are somewhat more positive, in contrast to youngsters taking other vocational specialisations in Preparatory Vocational Education who are more negative about the possible consequences of technological progress.

\subsection{The image of technical education}

To determine the relative image of technical education, the students were asked to rank various vocational options on a number of points. ${ }^{9}$ Each group of respondents was asked to rank the most important types of training at the level that directly follows on from their current educational level. For students in Preparatory Vocational Education and Lower General Secondary Education (LGSE), this means that they must place four course options within Intermediate Vocational Education in order of preference. Senior General Secondary Education students must rank six options at the Higher Vocational Education level, and Pre-university Education students must rank seven options at the university level.

The average place of the technical course in a particular ranking is taken as an indication of the (relative) image of technical education as regards that particular

\footnotetext{
${ }^{9}$ A similar method is used by Kodde and Ritzen (1986).
}

point. This method also provides an idea of the most important competitors to technical subjects. The image is expressed using a scale ranging from 0 to 100 , with the aid of the following simple indicator:

$I=100-\frac{100}{n-1}(\bar{x}-1)$

where $I$ is the indicator of the relative image of technical education; $n$ the number of educational options which are distinguished, i.e. four options for Preparatory Vocational Education/Lower General Secondary Education, six for Senior General Secondary Education, and seven for Pre-university Education; and $\bar{x}$ the average position of the technical option in the ranking.

This indicator has a value of 0 if technical education has a strong negative image in comparison to the other options, and a value of 100 would indicate a strong positive image, in relative terms. This indicator includes a partial compensation for the varying numbers of options for further education that the students at the various levels are asked to rank.

Table 5 shows the image of technical education as regards the labour market perspectives of this vocational specialisation, i.e. the probability of obtaining work and the chance of having a high income. This data also indicates the students' expectations of the economic value of a course. In general, students apparently consider that people with a technical

Table 5

The relative image of the labour market perspectives of technical education, by educational category and gender

\begin{tabular}{lll}
\hline Educational category & Probability of work & High income \\
\hline PVE: technology & & \\
$\quad$ Boys & 85 & 73 \\
Girls & $59(6.03)$ & $58(4.15)$ \\
PVE: other & & \\
$\quad$ Boys & 59 & 57 \\
Girls & $40(5.27)$ & $47(2.39)$ \\
LGSE & & \\
Boys & 70 & 61 \\
Girls & $41(12.04)$ & $51(4.58)$ \\
HGSE & & 71 \\
Boys & 79 & $64(2.91)$ \\
Girls & $63(5.93)$ & \\
\hline
\end{tabular}

$0=$ strong negative image $; 100=$ strong positive image; $t$-value differences between boys and girls are in parentheses. 
education have a rather good chance of getting a job, but it is striking that girls have a much more negative image of the employment opportunities of technically trained workers than boys. Moreover, it can be seen that youngsters taking the other vocational specialisations of Preparatory Vocational Education are more likely to have negative views of the employment opportunities for people with a technical vocational specialisation. These students expect that school-leavers from Intermediate Health Care and Services Education and Intermediate Commercial and Administrative Education will find a job more easily.

There is a similar pattern of expectations among students as regards the expected probability of earning a relatively high income. Once again, youngsters have a quite favourable image of technical education. Although the girls again have a lower estimate of the future income of people with a technical education, the difference between the girls' and boys' views is clearly smaller in this respect than it was in relation to the expected probability of getting work with a technical education. Students in the other vocational specialisations of Preparatory Vocational Education, and in Lower General Secondary Education, have the least favourable image of the expected incomes of people with a technical education. They expect that people with an Intermediate Commercial and Administrative Education will earn the most.

If we compare the image that the students have of the labour market perspectives of technical education with more actual information on these perspectives, it can be concluded that the students have a fairly accurate idea of the actual situation in the labour market, as regards the relative probabilities of getting work and the earnings ratios between the various educational options (see ROA, 1995; Cörvers et al., 2002). There is, however, an excessively optimistic idea of the labour market position of people with a commercial education, in relation to other kinds of education, which naturally has a negative effect on the expected relative labour market position of technical education. It can also be seen that, on the basis of the labour market data which is available now, there are no indications that the relative position of technically educated women is worse than the relative position of men with the same educational background. The negative image that technical education has among girls thus appears to be groundless.
The third element of the image of technical education we analysed relates to a number of qualitative aspects of the work, which the students would expect to obtain with a technical education. ${ }^{10}$ Table 6 gives an overview of the image that young people have of the work obtained with a technical education. ${ }^{11}$ Many of the students think that people with a technical education are relatively often required to do physically heavy work. The image of technical education in this respect is particularly negative among the youngsters that take the technical vocational specialisation of Preparatory Vocational Education. In contrast, youngsters have a much more favourable image of the probability that people with a technical education will have a mentally demanding job (stress). They generally do not expect that people with a technical education would encounter stress in their work.

The students considered that people with a technical education have a fairly high probability of entering an occupation which often involves dirty work. It is striking that the students in the technical vocational courses of Preparatory Vocational Education once again have the most negative view. Furthermore, the girls in the other vocational specialisations within Preparatory Vocational Education and in Senior General Secondary Education or University Preparatory Education have a clearly more negative image of the quality of the work of people with a technical education than do the boys in these educational categories. As regards the expected probability of having boring work, there is a clear difference between the views of boys and girls. Where boys categorize the work of people with a technical education as certainly not boring, girls consider the probability of boring work as much greater for technical education than for the other educational categories. A similar difference in image is found in relation to the degree of independence which people with a technical education are expected to have, in comparison to those with other educational backgrounds. Girls less often think that people with a technical education will find a job in which they have some independence. The image that boys

\footnotetext{
10 As early as 1776, Adam Smith (1776) pointed out that the supply of labour for a particular function was influenced not by the wages per se, but by the 'net advantages', which include qualitative aspects of the work.

${ }^{11}$ In the questionnaire the students had to interpret the terms mentioned, such as 'dirty work', themselves.
} 
Table 6

The relative image of technical education as regards the qualitative aspects of the work, by educational category and gender

\begin{tabular}{|c|c|c|c|c|c|}
\hline Educational category & Physically heavy work & Stress & Dirty work & Boring work & Independence \\
\hline \multicolumn{6}{|l|}{ PVE: technology } \\
\hline Boys & 31 & 67 & 39 & 80 & 70 \\
\hline Girls & $30(0.36)$ & $69(0.49)$ & $35(1.07)$ & $58(6.10)$ & $50(4.51)$ \\
\hline \multicolumn{6}{|l|}{ PVE: other } \\
\hline Boys & 36 & 63 & 45 & 61 & 54 \\
\hline Girls & $41(1.65)$ & $60(0.90)$ & $33(4.45)$ & $44(5.61)$ & $40(4.27)$ \\
\hline \multicolumn{6}{|l|}{ LGSE } \\
\hline Boys & 38 & 65 & 46 & 67 & 55 \\
\hline Girls & $46(3.38)$ & $64(0.82)$ & $43(1.37)$ & $50(7.17)$ & $48(2.67)$ \\
\hline \multicolumn{6}{|l|}{ HGSE } \\
\hline Boys & 47 & 68 & 43 & 63 & 56 \\
\hline Girls & $46(0.09)$ & $69(0.43)$ & $38(2.37)$ & $40(6.99)$ & $48(3.03)$ \\
\hline
\end{tabular}

$0=$ strong negative image; $100=$ strong positive image; $t$-value differences between boys and girls are in parentheses.

have of technical education in this respect is generally favourable, but not as positive as its image as regards the expected probability of getting a job which is not boring.

The students' perceptions of the qualitative aspects of the work of people with a technical education, in comparison to other educational options, have also been compared with the empirical data which is available. This data is derived from the labour supply survey prepared by the Organisation for Strategic Labour Market Research (see Allaart et al., 1993). It can be seen that the image that the students have of the qualitative aspects of the work of people with a technical education is not as close to reality as their image of the more quantitative aspects of their position in the labour market was. The probability of having work which is physically heavy with a technical education, in particular, is overestimated by the students. This applies for both the lower and higher levels. At the same time, the Preparatory Vocational Education and Lower General Secondary Education students, especially, have too favourable an image of courses in the service sector and health care in this respect. Moreover, students are in error in thinking that people with a technical education are more likely to have to do dirty work. Particularly at the higher level, there is hardly any dirty work. The youngsters taking the other vocational specialisations in Preparatory Vocational Education, in particular, have too negative an image of the probability of facing boring work and the degree of independence in work of people with a technical education, in relation to other types of education. $^{12}$

As regards the probability of boring work, these students' images of the occupational field open to people with Intermediate Health Care and Services Education are too favourable. They also overestimate the relative degree of independence of those with a commercial education. Among the Senior General Secondary Education and Pre-university Education students, in particular, the commercial/legal option had an unjustified better image than Higher Vocational Education and University Education in technical fields, as regards the degree of independence available in the work.

\section{The choice for technical studies and jobs}

\subsection{The funnel to technology}

Students' choice for a technical vocational specialisation can be illustrated in terms of a funnel, which narrows in three steps. As it narrows, the flows available to enter technological fields are reduced. Particularly among girls, the output end of the funnel is very small. This is shown in Fig. 1. The funnel begins at primary school, where in theory $100 \%$ of students could potentially flow through to technological fields. ${ }^{13}$ At

\footnotetext{
12 Of course 'boring work' is a very subjective concept.

13 Obviously, children in primary school may already have developed some preference for a particular field.
} 


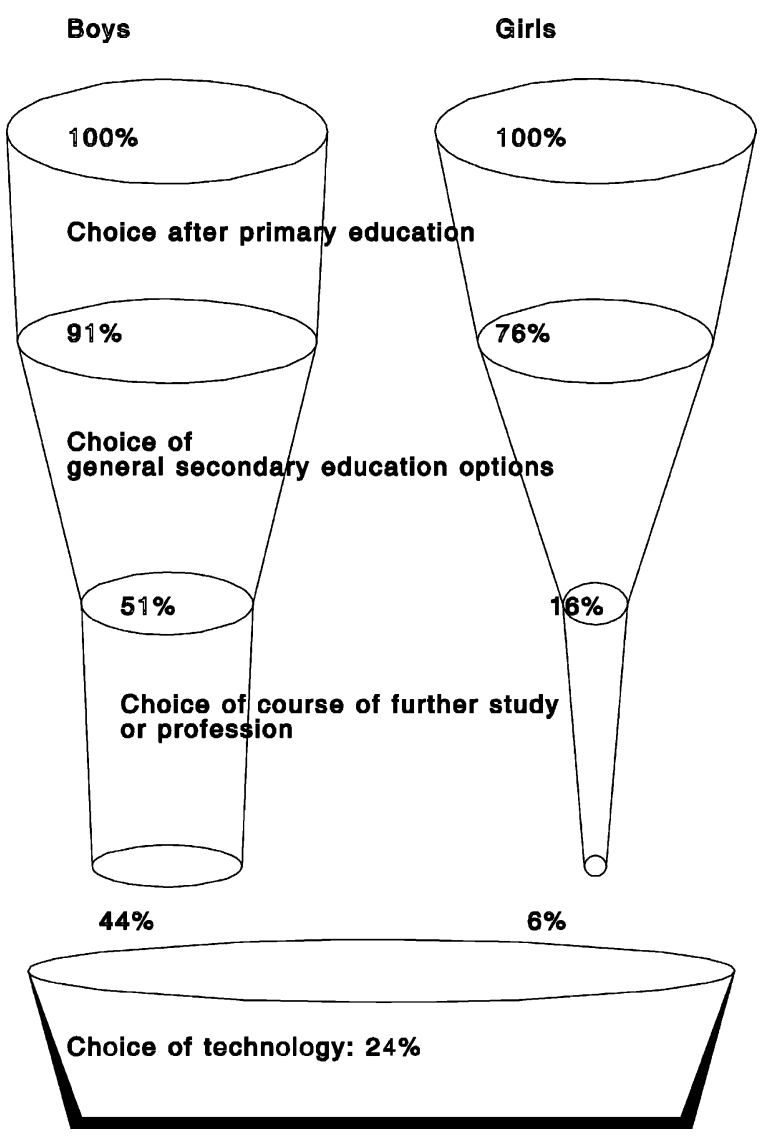

Fig. 1. The funnel leading to technology, by gender.

the first decision-point, at the end of primary school when they are 12 years old, the potential flows to technical fields are limited to $91 \%$ of the boys and $76 \%$ of the girls, since $9 \%$ of the boys and $24 \%$ of the girls choose other vocational specialisations in Preparatory Vocational Education. ${ }^{14}$

Students in General Secondary Education have to select a cluster of subjects at the end of the third or fourth year of study, when they are 15 or 16 years old. This decision-point also leads to a narrowing of the funnel. Thirty-nine percent of the boys, and just $18 \%$ of the girls, select a group of subjects with a strong technological orientation. The selection of subjects in Senior General Secondary Education and

\footnotetext{
${ }^{14}$ However, a small number of these youngsters do eventually end up in a technological field. An allowance is made for this in the final outflow from the 'funnel'.
}

Table 7

Students' intended choices of work or study in technological fields, by educational category and gender

\begin{tabular}{llc}
\hline Educational category & Boys $(\%)$ & Girls $(\%)$ \\
\hline PVE: technology & 78 & 22 \\
PVE: other & 15 & 2 \\
LGSE & 39 & 5 \\
HGSE & 31 & 7 \\
\hline
\end{tabular}

Pre-university education means that the technological options remain open for about half of all boys and just one-sixth of the girls who completed primary education.

After the more or less 'final' choice of further education in Intermediate Vocational Education, Higher Vocational Education, or University Education, or of an occupation, just $24 \%$ of all young people actually end up in technical fields. For the boys the flows reaching technological fields are reasonably large, at $44 \%$, but the successive constrictions in the funnel mean that just $6 \%$ of the girls flow to technical fields. Moreover, it must be noted that these percentages are based on the unrealistic assumption that all those with a technical education enter the labour market in a technical occupation.

If the percentages given above are broken down by educational category (Table 7), it can be seen that almost $80 \%$ of the boys taking the technical vocational specialisation in Preparatory Vocational Education intend to continue in technical fields, whereas only about $20 \%$ of the girls who take this specialisation intend ultimately to enter a technologically orientated occupation. As might be expected, interest in technical fields among youngsters that take the other vocational specialisations in Preparatory Vocational Education is fairly limited. Almost $40 \%$ of the boys in Lower General Secondary Education choose a technical field, but the girls in this educational category also appear to have very little interest in technological options. A similar situation can be seen at the level of Senior General Secondary Education and Pre-university Education.

\section{Estimation results}

To determine which factors are most important for the choice of a technical option, a binomial logit model 
has been specified (see, for example, Amemiya, 1981). As already noted, our analysis incorporates the possible influences not only of economic motives, personal characteristics and social backgrounds, but also of the image which students have of working in technical jobs and their view on technological developments. ${ }^{15}$

Table 8 shows the estimation results. The results show that the labour market perspectives of technical education and the qualitative aspects of the work of people with a technical education, have a significant positive effect on the proportion of students who choose a technical career. However, the coefficient shows that this effect is not great. The choice for a technical specialisation is much more affected by the youngsters' interests in technological developments and their school grades in Maths and Sciences. It is, however, striking that the students' own estimates of their abilities in these subjects have no significant influence. ${ }^{16}$ Moreover, even controlled for differences in interest in technological developments and school grades, girls much less often choose for a technical study or job. Just $9 \%$ of the girls with high grades for Maths and Sciences choose for the technical field, compared to $32 \%$ of the boys with good grades for these subjects. Also youngsters who find 'getting along with people' the most important thing for their own future are less likely to choose a technical occupation. These students mainly choose occupations in the medical and care-giving field. Furthermore, we find that in contrast to their interest in technical subjects, students' opinions about the economic and social consequences of technological progress does not have a significant influence on their choice of technological fields. Students' ethnic backgrounds ${ }^{17}$

\footnotetext{
15 Because not all the questions with respect to the personal characteristics and social backgrounds were included in the questionnaire used for students in Preparatory Vocational Education, the results presented relate only to students in Lower General Secondary Education, Senior General Secondary Education, and Pre-university Education.

16 The two variables are of course to some extent correlated, although the relation between students' own estimates of their abilities in Mathematics and Sciences and their actual school grades for these subjects is much weaker among the girls.

${ }^{17}$ In fact, only a small number of the students in Lower General Secondary Education, Senior General Secondary Education and University Preparatory Education in the sample have non-Dutch backgrounds.
}

Table 8

Estimation results from the probit model of LGSE and HGSE students' choices regarding technological or non-technological fields (standard errors in parentheses)

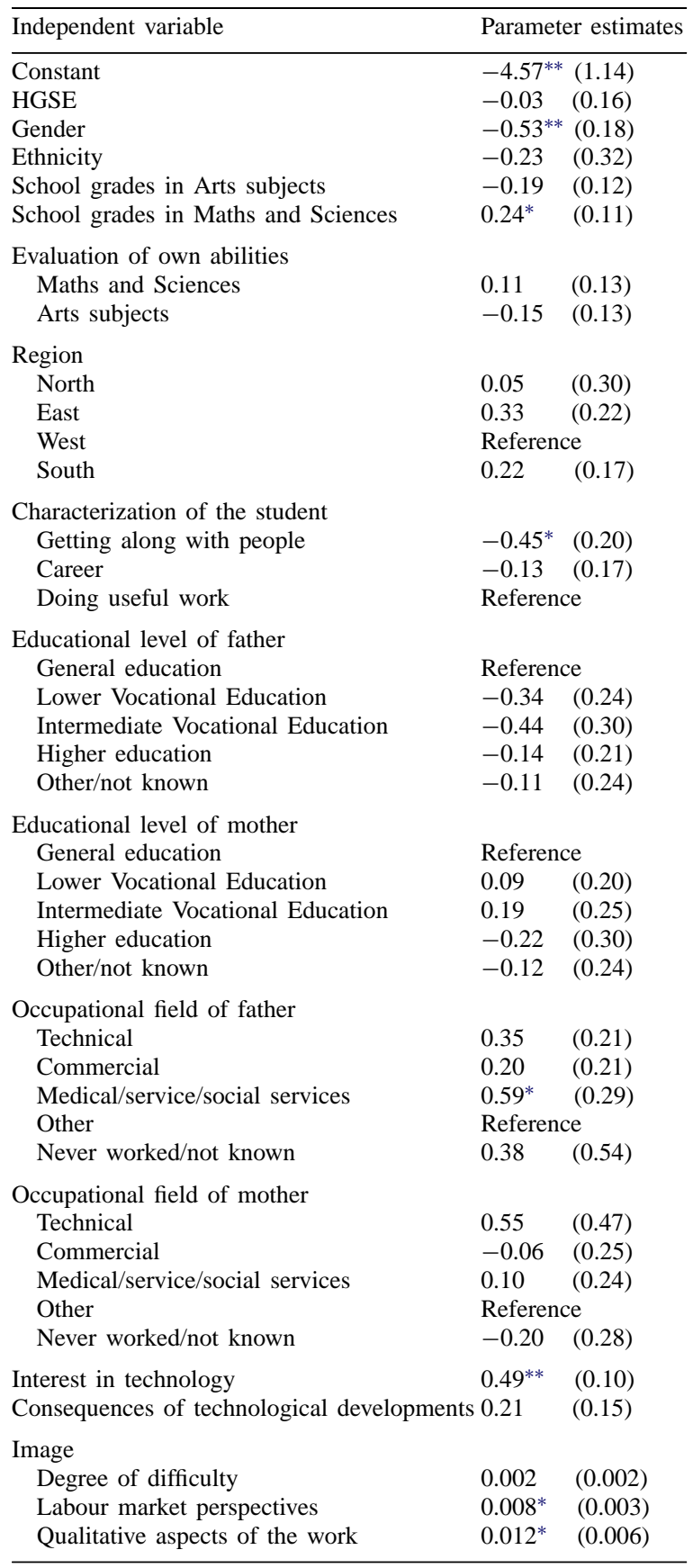

$N=622, \log$ likelihood $=-198.30$.

* Significant $5 \%$ level.

** Significant $1 \%$ level. 
and the regions in which they live appear to have scarcely any influence. Moreover, neither the field in which their parents worked, nor the educational level of the parents, plays a significant role in students' decisions to enter, or not to enter, a technical field. This result shows that the social background of youngsters does not play a direct role in determining the vocational choice of youngsters as stated by social stratification theory. However, there may be an indirect effect on youngsters' vocational choice as social backgrounds may determine someone's interest in technological developments and cognitive abilities.

\section{Conclusions and policy implications}

In this paper, we analysed the relation between, on the one hand, the choices of students in secondary education for technical studies and occupations and, on the other hand, their opinion on technological developments, the image that they have of technical education and the work of people who have a technical education and their social backgrounds. In our empirical model various economic and socio-psychological models are incorporated. Our estimation results show that both poor school grades in Maths and Sciences and lack of interest in technology as such is a crucial problem as regards the selection of a technical field of work. Moreover, girls rarely choose for a technical study even if they have good grades for Maths and Sciences. The choice for technical studies and jobs is only slightly affected by economic motives, whereas negative views on the economic and social consequences of technological development and the social background of students do not affect the choice for technical studies or jobs.

Increasing the interest of youngsters in science and technology is a major challenge for both industry and schools in order to provide optimal conditions for technology-intensive economic growth. Trade and industry should contribute to eliminating the negative image of the work of people with a technical education, especially among girls.

Public policy to increase the inflow of youngsters in technical studies and jobs usually depends on mass campaigns promoting the labour market perspectives of technical studies. However, as we found the latter is not the main determent of youngsters' choice for a technical vocational specialisation, it would be better to focus policies that intend to increase the inflow of youngsters in the technical field on a long-term strategy to increase the interest in technological innovation at young ages and improving the quality of education in Math and Sciences. Moreover, campaigns should focus much more on specific target groups, such as the girls with good grades in mathematics and sciences.

\section{References}

Allaart, P.C., Kunnen, R., Praat, W.C.M., de Voogd-Hamelink, A.M., Vosse, J.P.M., 1993. Trendrapport aanbod van arbeid 1993. OSA Report No. 17, Den Haag.

Amemiya, T., 1981. Qualitative response models: a survey. Journal of Economic Literature 19, 1483-1536.

Becker, G.S., 1962. Investment in human capital: a theoretical analysis. Journal of Political Economy 70, 9-49.

Blau, P.M., Ducan, O.D., 1967. The American Occupational Structure. Wiley, New York.

Blau, F.D., Hendricks, W.E., 1979. Occupational segregation by sex: trends and prospects. Journal of Human Resources 14, 197-210.

Borghans, L., de Grip, A., Heijke, H., 1996. Labor market information and the choice of vocational specialization. Economics of Education Review 15 (1), 59-74.

Boudon, R., 1974. Education, Opportunity and Social Inequality. Wiley, New York.

Cörvers, F., de Grip, A., Heijke, H., 2002. Beyond manpower planning: a labour market model for The Netherlands and its forecasts to 2006. In: Neugart, M., Schömann, K. (Eds.), Forecasting Labour Markets in OECD Countries. Edward Elgar, Cheltenham, pp. 185-223.

Eccles, J.S., 1987. Gender roles and women's achievement-related decisions. Psychology of Women Quarterly 11, 135-172.

European Commission, 1993. Growth, competitiveness, employment: the challenges and ways forward to the 21 st century. Bulletin of the European Communities. Supplement 6/1993. Office for Official Publication of the European Communities, Luxembourg.

Fishbein, M., Ajzen, I., 1975. Beliefs, Attitude, Intention and Behaviour. Addison-Wesley, Massachusetts.

de Klerk Wolters, F., 1989. The attitude of pupils towards technology. Thesis, Eindhoven.

Kodde, D.A., Ritzen, J.M.M., 1986. Vraag naar hoger onderwijs Eindrapport. Serie beleidsgerichte studies Hoger Onderwijs en Wetenschappelijk Onderzoek nr. 6. Ministerie van Onderwijs en Wetenschappen, Den Haag.

Mueller, D.J., 1986. Measuring Social Attitudes: A Handbook for Researchers and Practitioners. Teachers College Press, New York/London. 
Murphy, K.M., Scheifer, A., Vishny, R.W., 1991. The allocation of talent: implications for growth. Quarterly Journal of Economics 106, 505-530.

Pearson, R., Jagger, N., Connor, H., Perrymon, S., de Grip, A., Marey, P., Cörvers, F., 2000. Assessing the Supply and Demand for Scientists and Technologists in Europe. IES-Report 377, Brighton.

Research Centre for Education and the Labour Market, 1995. The Labour Market by Education and Occupation to 2000. ROA Report 1995/3E, Maastricht.
Schultz, T.W., 1961. Investment in human capital. The American Economic Review 51, 1-17.

Sieben, I., Huinink, J., De Graaf, P.M., 2001. Family background and sibling resemblance in educational attainment: trends in the former FRG, the former GDR and The Netherlands. European Sociological Review 17, 401-430.

Smith, A., 1776. The Wealth of Nations. Adam \& Ch. Black, Edinburgh. 